\title{
Tumor-suppressing effects of microRNA-429 in human renal cell carcinoma via the downregulation of Sp1
}

\author{
DEYAO WU $^{1 *}$, XIAOBING NIU $^{2 *}$, HUIXING PAN $^{1}$, YUNFENG ZHOU $^{1}$, \\ ZICHUN ZHANG ${ }^{1}$, PING QU ${ }^{1}$ and JIAN ZHOU ${ }^{1}$ \\ ${ }^{1}$ Department of Urology, The Fourth Affiliated Hospital of Nantong Medical College, \\ Yancheng City No. 1 People's Hospital, Yancheng, Jiangsu 224001; ${ }^{2}$ Department of Urology, \\ Huai'An First People's Hospital, Nanjing Medical University, Huai'an, Jiangsu 223300, P.R. China
}

Received December 22, 2014; Accepted June 3, 2016

DOI: $10.3892 / 01.2016 .4953$

\begin{abstract}
MicroRNA (miR)-429 has been frequently reported to be downregulated in various tumors, including renal cell carcinoma (RCC), nasopharyngeal carcinoma, Ehrlich ascites tumor cells, gastric cancer, non-small cell lung cancer and endometrial endometrioid carcinoma. The present study investigated the effects of miR-429 on human RCC A498 and 786-O cells. Following transfection of cells with miR-429 mimics and scrambled control, MTT, cell migration, cell invasion and luciferase assays were performed. In addition, western blotting was performed in order to assess the expression of specificity protein $1(\mathrm{Sp} 1)$, which was predicted to be a target of miR-429 by TargetScan. The present results revealed that miR-429 inhibited cell proliferation, migration and invasion of 786-O and A498 cells. In addition, the present results demonstrated that miR-429 overexpression downregulated Spl protein expression, which provides evidence that miR-429 may directly target Sp1 in RCC. These results suggest that miR-429 may be investigated for use as a predictive marker for early detection of tumor metastasis and blocking RCC cells from becoming invasive.
\end{abstract}

\section{Introduction}

Renal cell carcinoma ( $\mathrm{RCC}$ ) represents the most common malignancy of the adult kidney and comprises $2-3 \%$ of all malignant tumors in adults (1). In 2014, there were 63,920 novel cases of kidney cancer diagnosed in the USA (2). RCC accounts for $\sim 90 \%$ of all kidney malignancies, with a rising incidence

Correspondence to: Professor Jian Zhou, Department of Urology, The Fourth Affiliated Hospital of Nantong Medical College, Yancheng City No. 1 People's Hospital, 15 Yuehe Road, Yancheng, Jiangsu 224001, P.R. China

E-mail: luqiang0405@163.com

*Contributed equally

Key words: renal cell carcinoma, Sp1 miR-429 over the past decade (3). RCC is an epithelial neoplasm, since it originates from the transformation of cells that constitute the epithelium of the proximal convoluted tubule (4). RCC includes several histological subtypes that possess distinct biological behaviors and prognoses. The principal histological subtypes are as follows: Clear cell RCC (75-80\% of RCC); papillary or chromophile RCC (10-15\%); and chromophobe RCC (4-6\%) (4). Although the majority of patients with early-stage RCC may be cured surgically, 10-20\% of patients present with metastasis at the time of diagnosis (5-7). In addition, $50 \%$ of RCC patients that have undergone curative surgery may be expected to develop a recurrence with distant metastasis, and the prognosis of RCC patients with metastatic or recurrent disease is poor, with a 5-year survival rate of <20\% (8). The most common sites of metastatic spread in RCC are lung, bone, adrenal gland, liver and brain, and more than one organ is often involved (9). Therefore, the molecular mechanisms of cancer cell dissemination from the primary tumor are important when considering treatment and observational strategies for RCC patients.

MicroRNAs (miRs) are 21-25 nucleotide single-stranded, non-coding RNA molecules that exert their functions by binding to the 3'-untranslated regions (UTRs) of their corresponding mRNA targets, which leads to target mRNA cleavage or translational repression (10). It has been widely accepted that miRs are important in numerous biological processes, including differentiation, proliferation, apoptosis, cell cycle, migration and invasion (11). Research has revealed that a single miR targets hundreds of mRNAs, and $~ 50 \%$ of $\mathrm{miR}$ genes are located in cancer-associated chromosomal regions (12). In addition, mature miRs regulate the expression of $\sim 10-30 \%$ of all human genes (13). miRs function as either tumor suppressors or oncogenes, depending on the genes that they target (14); tumor suppressive miRs are usually downregulated, while oncogenic miRs are upregulated in cancer (15). Recent evidence indicates that the aberrant regulation of miRs are important in RCC pathogenesis (16). Therefore, miRs are being investigated as potential biomarkers for diagnosis and prognosis of human malignancies, due to their tissue and disease-specific expression and regulatory functions (17).

miR-429 has been frequently reported to be downregulated in various tumors, including RCC (18), nasopharyngeal 
carcinoma (19), Ehrlich ascites tumor cells (20), gastric cancer (21), non-small cell lung cancer (22) and endometrial endometrioid carcinoma (23). However, the function of miR-429 has yet to be elucidated in RCC. The aim of the present study was to investigate the effect of miR-429 on RCC and to elucidate its underlying mechanisms.

\section{Materials and methods}

Cell culture and transfection. Human RCC 786-O and A498 cell lines were purchased from the Shanghai Institute of Cell Biology, Chinese Academy of Science (Shanghai, China). The cells were cultured in RPMI-1640 medium (Gibco ${ }^{\circledR}$; Thermo Fisher Scientific, Inc., Waltham, MA, USA) supplemented with $10 \%$ heat-inactivated fetal calf serum (FCS; Gibco $\left.^{\circledR}\right), 100 \mathrm{U} / \mathrm{ml}$ penicillin and $100 \mathrm{mg} / 1$ streptomycin. Cultures were maintained at $37^{\circ} \mathrm{C}$ in a humidified atmosphere with $5 \% \mathrm{CO}_{2}$.

Mature miR-429 mimics (UAAUACUGUCUGGUAAAA CCGU), scrambled control (NC; UUCUCCGAACGUGUC ACGUTT) and luciferase reporter plasmid were purchased from Shanghai GenePharma Co., Ltd. (Shanghai, China). Transient transfection of miR-429 mimics and/or plasmid were performed using Lipofectamine ${ }^{\circledR} 2000$ (Invitrogen $^{\text {TM }}$; Thermo Fisher Scientific, Inc.), according to the manufacturer's protocol.

Cell viability assay. A MTT assay was used to estimate the proliferation ability of the cells. Cells transfected with miR-429 mimics or NC were seeded in 96-well plates at a density of 3,000 cells/well for 24, 48, 72, 96, 120 and $144 \mathrm{~h}$. Briefly, the cells were incubated with $20 \mathrm{ml} \mathrm{MTT}(5 \mathrm{mg} / \mathrm{ml})$ for $4 \mathrm{~h}$ at $37^{\circ} \mathrm{C}$. The plates were agitated and $200 \mu \mathrm{l}$ dimethyl sulfoxide was added to solubilize the crystals for $20 \mathrm{~min}$ following the removal of the culture supernatant. Absorbance was measured at $490 \mathrm{~nm}$ using an automatic multi-well spectrophotometer (Bio-Rad Laboratories, Inc., Hercules, CA, USA). The suppression rate was calculated using the following formula: Suppression rate $=[1$ - optical density $\left.\left(\mathrm{OD}_{\mathrm{miR}-429} / \mathrm{OD}_{\mathrm{NC}}\right)\right]$ x 100. All the experiments were performed in triplicate.

Cell migration and invasion assay. Cell migration and invasion assays were evaluated using Transwell chambers (Corning Incorporated, Corning, NY, USA). The upper and lower culture compartments were separated by polycarbonate filters with a $8 \mathrm{~mm}$ pore size. Prior to the invasion assays, the filters of the Transwell chambers were coated with $30 \mu \mathrm{g}$ Matrigel (BD Biosciences, San Jose, CA, USA) to form a reconstituted basement membrane. Transfected cells (miR-429 mimics and $\mathrm{NC}$ ) in the log phase were treated with trypsin/EDTA solution, washed once with serum-containing RPMI-1640 medium, centrifuged (at $200 \mathrm{x}$ g for $10 \mathrm{~min}$ ) and re-suspended as single-cell solutions. A total of $1 \times 10^{5}$ cells in $0.2 \mathrm{ml}$ serum-free RPMI-1640 medium were seeded into the Transwell chambers. The lower chamber contained RPMI -1640 supplemented with $20 \%$ FCS to stimulate invasion. The cells were incubated for $12 \mathrm{~h}$ for the migration assay and $24 \mathrm{~h}$ for the invasion assay. Non-migrating and -invading cells on the top of the membrane were removed by scraping. Cells that migrated to the bottom surface of the insert were fixed with $100 \%$ methanol, stained with $0.5 \%$ crystal violet, and subjected to microscopic inspection (magnification, x200). Values for invasion and migration were obtained by counting five fields per membrane, and represent the average of three independent experiments.

Western blotting. Western blotting was performed as described previously (24). Primary antibodies used in the present study were rabbit anti-human specificity protein 1 (SP1) monoclonal antibody (1:1,000 dilution; catalog no. 9389; Cell Signaling Technology, Inc., Danvers, MA, USA) and rabbit anti-human anti- $\beta$-actin monoclonal antibody (1:1,000 dilution; catalog no. AP0060; Bioworld Technology, Inc., Louis Park, MN,USA). Total protein was extracted using ice-cold radioimmunoprecipitation assay buffer (Beyotime Institute of Biotechnology, Jiangsu, Haimen, China). Equal amounts of protein were subjected to $10 \%$ sodium dodecyl sulfate polyacrylamide gel electrophoresis and transferred to polyvinylidene difluoride membranes (Bio-Rad Laboratories, Inc.). Following blocking with $5 \%$ non-fat milk in Tris-buffered saline with $0.1 \%$ Tween 20 , the membranes were incubated overnight at $4^{\circ} \mathrm{C}$ with the appropriate primary antibody. Following washing, the blots were incubated with goat anti-rabbit horseradish peroxidase-conjugated secondary antibody (1:2,000 dilution; catalog no. 7074; Cell Signaling Technology, Inc.) at room temperature for $1 \mathrm{~h}$. The intensity of each blot was read and analyzed with AlphaEaseFC ${ }^{\text {тм }}$ software (version 4.0.1; Cell Biosciences, Palo Alto, CA, USA). $\beta$-actin was used as a loading control.

Luciferase assay. Reporter plasmids (pmirGLO-SP1-3'UTR wild-type and pmirGLO-SP1-3'UTR mutant) were synthesized and purified by GenePharma. Cells were plated in a 12-well plate at $\sim 90 \%$ confluence and transfected with reporter plasmid, miR-429 mimics or NC using Lipofectamine 2000. Each sample was also cotransfected with $0.05 \mu \mathrm{g}$ pRL-CMV plasmid expressing Renilla Luciferase (Promega Corporation, Madison, WI, USA), as an internal control for transfection efficiency. Subsequent to $24 \mathrm{~h}$, luciferase activity was measured using the Dual-Luciferase ${ }^{\circledR}$ Reporter Assay System (Promega Corporation), according to the manufacturer's protocol. Firefly luciferase activities and Renilla luciferase activities were measured with a luminometer (Tecan Group, Ltd, Männedorf, Switzerland). Each assay was replicated three times.

Statistical analysis. Data are presented as the mean \pm standard deviation, and compared using Student's t-test in Stata version 10.0 software (StataCorp LP, College Station, TX, USA). Double-tailed $\mathrm{P}<0.05$ was considered to indicate a statistically significant difference.

\section{Results}

miR-429 suppresses cell proliferation in RCC cell lines. MTT assays were employed to detect the proliferation of 786-O and A498 cell lines following transfection with miR-429 or NC. As shown in Fig. 1, overexpression of miR-429 in 786-O and A498 cells inhibited cell proliferation. Compared with the NC-transfected cells, the suppression rate of miR-429 reached $33.50 \pm 2.90 \%$ in $786-\mathrm{O}$ cells $(\mathrm{P}=0.010)$ and $43.31 \pm 4.20 \%$ in A498 cells $(\mathrm{P}=0.002)$ following $144 \mathrm{~h}$ of treatment. 

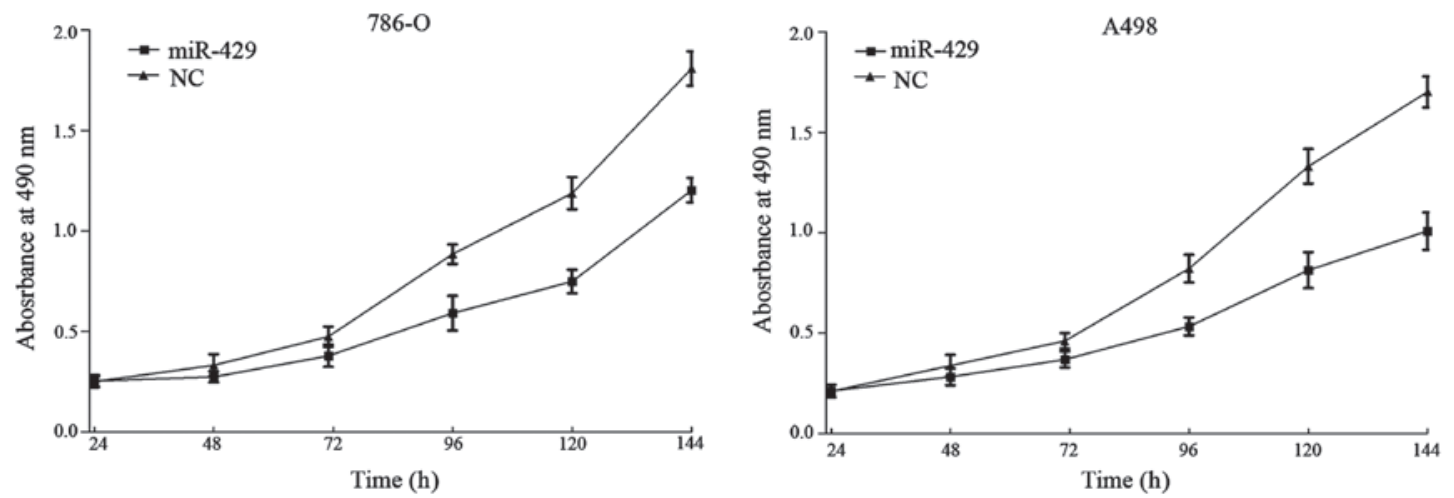

Figure 1. Cell proliferation was analyzed by MTT assay in human RCC 786-O and A498 cell lines. A growth curve is shown for each treatment at 0,24, 48, 72, 96, 120 and $144 \mathrm{~h}$ following transfection of cells with miR-429 mimics and NC. The results indicated that upregulation of miR-429 significantly suppressed cell proliferation in RCC cell lines. ${ }^{\mathrm{P}}<0.05$ vs. NC-transfected cells. miR, microRNA; RCC, renal cell carcinoma; NC, scrambled control.
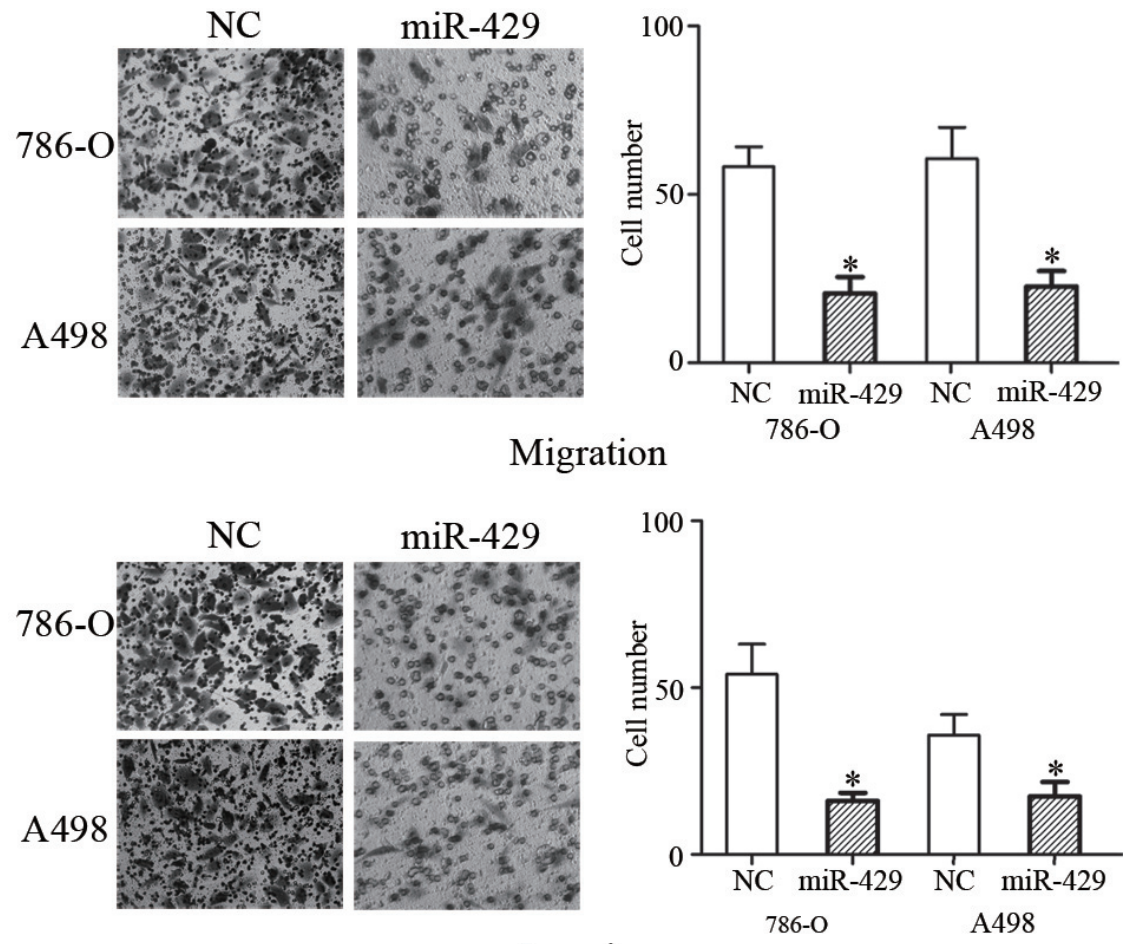

Invasion

Figure 2. Inhibition of tumor cell migration and invasion by miR-429 in human renal cell carcinoma 786-O and A498 cell lines. The results indicated that miR-429 inhibited cell migration and invasion in 786-O and A498 cells compared with NC-transfected cells (magnification, $\mathrm{x} 200$ ). " $\mathrm{P}<0.05$ vs. NC. miR, microRNA; NC, scrambled control.

miR-429 inhibits cell migration and invasion in RCC cell lines. To determine whether miR-429 regulates human RCC cell migration and invasion, migration and invasion assays were performed on miR-429 mimic- and NC-transfected RCC 786-O and A498 cell lines. As expected, overexpression of miR-429 significantly decreased the migration $(\mathrm{P}=0.024$ for $786-\mathrm{O}$ cells and $\mathrm{P}=0.029$ for $\mathrm{A} 498$ cells $)$ and invasion $(\mathrm{P}=0.020$ for $786-\mathrm{O}$ cells and $\mathrm{P}=0.039$ for $\mathrm{A} 498$ cells) capability of the 786-O and A498 cells (Fig. 2). These observations indicated that miR-429 was a negative regulator of RCC migration and invasion.

miR-429 suppresses the expression of Sp1 in RCC cell lines. TargetScan (version 5.2; www.targetscan.org) predicted that
Sp1 was a direct target gene of miR-429, and revealed that Sp1 mRNA contained a miR-429 7-nucleotide seed match at position 2490-2496 of the Sp1 3'-UTR (Fig. 3A).

Therefore, the present study performed western blot analysis to investigate whether Sp1 protein level was decreased following overexpression of miR-429. As shown in Fig. 3B, $\mathrm{Sp} 1$ was significantly decreased in $786-\mathrm{O}(\mathrm{P}=0.018)$ and A498 cell lines $(\mathrm{P}=0.012) 72 \mathrm{~h}$ subsequent to transfection of miR-429 compared with cells transfected with NC. These data reveal that Sp1 is a direct functional target of miR-429.

$S p 1$ is a direct target of $m i R-429$. To further confirm that Spl is a direct target for miR-429, a luciferase reporter assay was performed in RCC 786-O and A498 cell lines. As shown 
A Position 2490-2496 of Sp1 3' UTR 5'...ACUCACUgGaAuguaCAgUAUUU... hsa-miR-429 3' UGCCAAAAUGGUCUGUCAUAAU
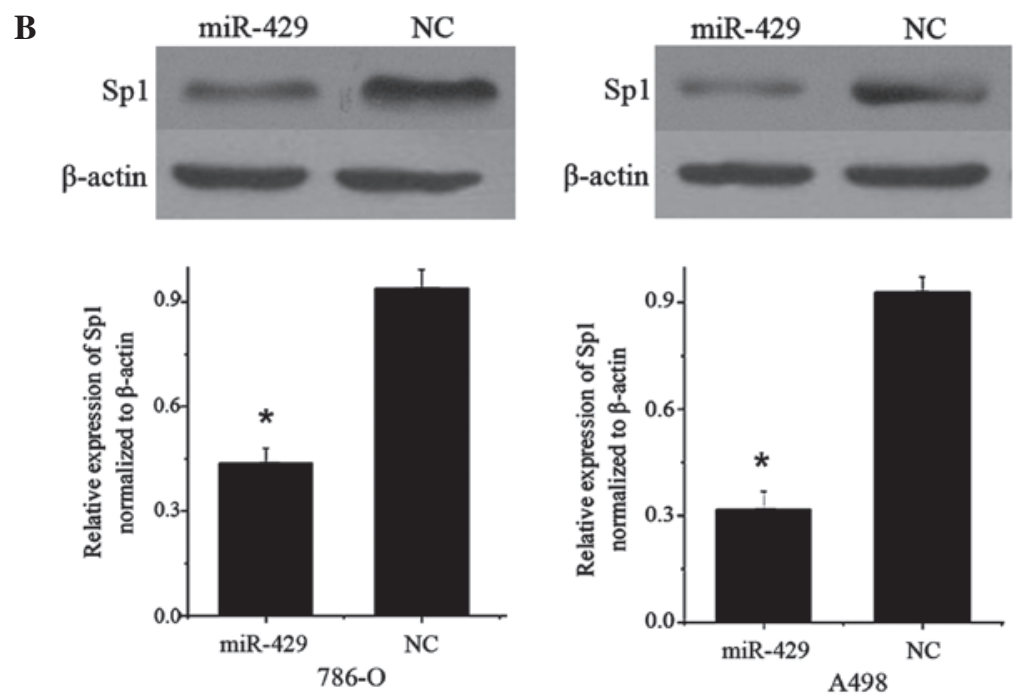

Figure 3. (A) TargetScan version 5.2 revealed that Sp1 mRNA contained a miR-429 7-nucleotide seed match at position 2490-2496 of the Sp1 3'-UTR. (B) $\mathrm{Sp1}$ protein expression was significantly decreased in human renal cell carcinoma 786-O and A498 cells following transfection with miR-429 mimic. "P<0.05 vs. NC. miR, microRNA; NC, scrambled control; Sp1, specificity protein 1; UTR, untranslated region.
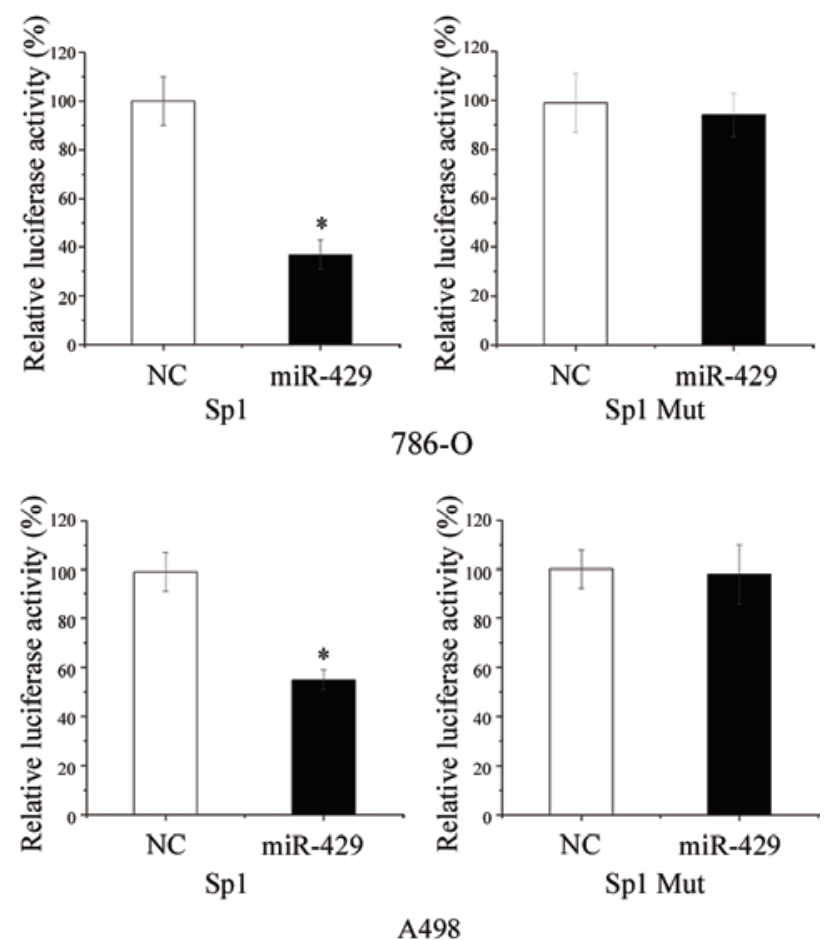

Figure 4. Sp1 may be a direct target of miR-429 in vitro. miR-429 suppressed Sp1 3'-UTR-luciferase activity by 63 and $44 \%$ in human renal cell carcinoma 786-O and A498 cells, respectively, following transfection with miR-429 mimic. This effect was abolished with Sp1 3'-UTR Mut. "P<0.05 vs. NC. miR, microRNA; NC, scrambled control; Sp1, specificity protein 1; Mut, mutated; UTR, untranslated region.

by Fig. 4, transfection of cells with miR-429 mimic significantly decreased the Sp1 3'-UTR luciferase reporter activity compared with cells transfected with NC. Overexpression of miR-429 suppressed Sp1 3'-UTR-luciferase activity by $63 \%$ in 786-O cells $(\mathrm{P}=0.020)$ and $44 \%$ in $\mathrm{A} 498$ cells $(\mathrm{P}=0.034)$.
In addition, this effect was abolished when the nucleotides in the seed binding sites of the Sp1 3'-UTR were mutated (Fig. 4).

The present results suggest that $\mathrm{Sp} 1$ is a target gene of miR-429. 


\section{Discussion}

miR-429 belongs to a small miR family, which includes miR-200c, miR-141, miR-200b and miR-200a (25), and is located on chromosome 1. Downregulation of miR-429 may be important in tumor progression, and previous studies have revealed that miR-429 is frequently downregulated in various tumors, including RCC (18), nasopharyngeal carcinoma (19), Ehrlich ascites tumor cells (20), gastric cancer (21), non-small cell lung cancer (22) and endometrial endometrioid carcinoma (23). However, miR-429 has been demonstrated to be upregulated in bladder cancer, and an increased expression was correlated with poor prognosis in serous ovarian carcinoma patients $(26,27)$. Therefore, miR-429 appears to be involved in carcinogenesis and cancer progression, and plays various roles depending on the type of cancer.

In gastric cancer, miR-429 inhibits the proliferation, migration and invasion of tumor cells. In addition, the expression levels of miR-429 in the tissues of gastric cancer patients with lymph node metastasis were significantly lower compared with patients without lymph node metastasis (28). In colorectal cancer, miR-429 was revealed to be significantly downregulated in the majority of tumor tissues investigated, particularly tissue from stages II and III, relative to adjacent or distant normal mucosa. Survival analysis also indicated a low expression of miR-429 is significantly associated with poor prognosis (29). Upregulation of miR-429 suppressed cell growth, invasion and the expression of epithelial-mesenchymal transition-association marker genes, including E-cadherin, catenin (CTNN) A1, CTNNB1, transferring N-terminal half-molecule, cluster of differentiation 44, matrix metallopeptidase 2, vimentin, Slug, Snail and zinc finger E-box binding homeobox (ZEB) 2 (18). These results suggest that downregulation of miR-429 in tumour cells may play a role in the development of cancer by enhancing cell proliferation and promoting cell migration and invasion.

Identification of miR-429 target genes is critical for understanding the role of miR-429 in tumorigenesis, and is important for defining novel therapeutic targets. Previous studies have demonstrated that miR-429 regulates oncogenic expression in human cells, including c-myc (28), onecut 2 (18), ZEB1 (30), v-crk avian sarcoma virus CT10 oncogene homolog-like (31) and B-cell lymphoma 2 (32). Therefore, upregulation of miR-429 or providing analogous pharmaceutical compounds exogenously may be effective cancer therapy for RCC, leading to the regulation of these oncogenic transcripts. The present results suggest multiple inhibitory effects of miR-429 in human RCC 786-O and A498 cell lines, including cell proliferation and invasion suppression, via the downregulation of the expression of $\mathrm{Sp} 1$. The present findings suggest that miR-429 may be used for the development of novel molecular markers and therapeutics for RCC.

$\mathrm{Sp} 1$ is an ubiquitously expressed transcription factor, and was the first transcription factor to be cloned from mammalian cells in 1983 (33). It maps to 12q13.1 and encodes a protein of 785 amino acids (34). Sp1 recognizes GC-rich regions and binds to DNA through three $\mathrm{C} 2 \mathrm{H} 2$-type zinc fingers in the C-terminal domain $(35,36)$. Each zinc finger of $\mathrm{Sp} 1$ recognizes three bases in one strand and a single base in the complementary strand, constituting a consensus binding sequence of 5'-(G/T)GGGCGG(G/A)(G/A)(C/T)-3' (37). Originally, $\mathrm{Sp1}$ was considered to be a general transcription factor required for transcription of a large number of 'housekeeping genes' (38). However, recently a study has indicated that many of these housekeeping genes are crucial in tumorigenesis and cancer progression (39). Consequently, Sp1 has been demonstrated to be important in tumor progression, including cell proliferation, angiogenesis, differentiation, apoptosis, migration and invasion, revealing it as an ideal target for cancer treatment (40).

Sp1 has been identified to be upregulated in various types of human cancer, including breast carcinoma (41), thyroid cancer (42), hepatocellular carcinoma (43), pancreatic cancer (44), colorectal cancer (45), gastric cancer (46) and lung cancer (47). Sp1 expression is tightly regulated throughout the various stages of tumorigenesis, which affects cancer progression (48). Previous studies concerning Sp1 expression in tumorigenesis suggest that increased transcription is the most important mechanism for $\mathrm{Sp} 1$ accumulation during cancer formation $(49,50)$. Sp1 contributes to cancer progression and is regulated by many miRs. In non-small cell lung cancer cells, miR-335 and miR-27b suppressed the proliferation, invasion and induced apoptosis in cells by targeting Sp1 $(51,52)$. In prostate cancer, Mao et al (53) demonstrated that miR-330 suppressed cell motility by targeting Sp1. In squamous cervical cancer, Wang et al (54) revealed that miR-375 inhibited cell migration and invasion by targeting Sp1. The present study revealed that miR-429 suppressed RCC cell viability, migration and invasion via the downregulation of Sp1. Therefore, Sp1 may be investigated as a predictive marker for the early detection of tumor recurrence, and be used in therapeutics to block RCC cells from becoming invasive.

In summary, the present study is, to the best of our knowledge, the first study to demonstrate that miR-429 contributes to cell viability, migration and invasion in RCC. The identification of candidate target genes of miR-429, such as Sp1, may provide an understanding of the potential carcinogenic mechanisms in $\mathrm{RCC}$. These findings have therapeutic implications and may be used for novel treatment strategies for RCC.

\section{References}

1. Escudier B: Emerging immunotherapies for renal cell carcinoma. Ann Oncol 23 (Suppl 8): viii35-viii40, 2012.

2. Siegel R, Ma J, Zou Z and Jemal A: Cancer statistics, 2014. CA Cancer J Clin 64: 9-29, 2014.

3. Xu S, Wu H, Nie H, Yue L, Jiang H, Xiao S and Li Y: AIF downregulation and its interaction with STK3 in renal cell carcinoma. PLoS One 9: e100824, 2014.

4. Srigley JR, Delahunt B, Eble JN, Egevad L, Epstein JI, Grignon D, Hes O, Moch H, Montironi R, Tickoo SK, et al: The international society of urological pathology (ISUP) vancouver classification of renal neoplasia. Am J Surg Pathol 37: 1469-1489, 2013.

5. Yang YQ and Chen J: Predictive role of vascular endothelial growth factor polymorphisms in the survival of renal cell carcinoma patients. Genet Mol Res 13: 5011-5017, 2014.

6. Flanigan RC, Campbell SC, Clark JI and Picken MM: Metastatic renal cell carcinoma. Curr Treat Options Oncol 4: 385-390, 2003.

7. Athar U and Gentile TC: Treatment options for metastatic renal cell carcinoma: A review. Can J Urol 15: 3954-3966, 2008.

8. Irani J: Sunitinib versus interferon-alpha in metastatic renal-cell carcinoma. Prog Urol 17: 996, 2007 (In French).

9. Toma MI, Erdmann K, Diezel M, Meinhardt M, Zastrow S, Fuessel S, Wirth MP and Baretton GB: Lack of ephrin receptor A1 is a favorable independent prognostic factor in clear cell renal cell carcinoma. PLoS One 9: e102262, 2014. 
10. Lai EC: Micro RNAs are complementary to 3' UTR sequence motifs that mediate negative post-transcriptional regulation. Nat Genet 30: 363-364, 2002.

11. Miao J, Wu S, Peng Z, Tania M and Zhang C: MicroRNAs in osteosarcoma: Diagnostic and therapeutic aspects. Tumour Biol 34: 2093-2098, 2013.

12. Ma XP, Zhang T, Peng B, Yu L and Jiang de K: Association between microRNA polymorphisms and cancer risk based on the findings of 66 case-control studies. PLoS One 8: e79584, 2013.

13. Berezikov E, Guryev V, van de Belt J, Wienholds E, Plasterk RH and Cuppen E: Phylogenetic shadowing and computational identification of human microRNA genes. Cell 120: 21-24, 2005.

14. Cimmino A, Calin GA, Fabbri M, Iorio MV, Ferracin M, Shimizu M, Wojcik SE, Aqeilan RI, Zupo S, Dono M, et al: miR-15 and miR-16 induce apoptosis by targeting BCL2. Proc Natl Acad Sci USA 102: 13944-13949, 2005.

15. Lee YS and Dutta A: MicroRNAs in cancer. Annu Rev Pathol 4: 199-227, 2009.

16. Xu X, Wu J, Li S, Hu Z, Xu X, Zhu Y, Liang Z, Wang X, Lin Y, Mao Y, et al: Downregulation of microRNA-182-5p contributes to renal cell carcinoma proliferation via activating the AKT/FOXO3a signaling pathway. Mol Cancer 13: 109, 2014.

17. Bartels CL and Tsongalis GJ: MicroRNAs: Novel biomarkers for human cancer. Ann Biol Clin (Paris) 68: 263-272, 2010 (In French).

18. Sun Y, Shen S, Liu X, Tang H, Wang Z, Yu Z, Li X and Wu M: MiR-429 inhibits cells growth and invasion and regulates EMT-related marker genes by targeting Onecut 2 in colorectal carcinoma. Mol Cell Biochem 390: 19-30, 2014.

19. Bartis D, Mise N, Mahida RY, Eickelberg O and Thickett DR: Epithelial-mesenchymal transition in lung development and disease: Does it exist and is it important? Thorax 69: 760-765, 2014.

20. Said NA and Williams ED: Growth factors in induction of epithelial-mesenchymal transition and metastasis. Cells Tissues Organs 193: 85-97, 2011.

21. Yang J and Weinberg RA: Epithelial-mesenchymal transition: At the crossroads of development and tumor metastasis. Dev Cell 14: 818-829, 2008.

22. Zhu W, He J, Chen D, Zhang B, Xu L, Ma H, Liu X, Zhang Y and Le H: Expression of miR-29c, miR-93, and miR-429 as potential biomarkers for detection of early stage non-small lung cancer. PLoS One 9: e87780, 2014.

23. Miyazono K: Transforming growth factor-beta signaling in epithelial-mesenchymal transition and progression of cancer. Proc Jpn Acad Ser B Phys Biol Sci 85: 314-323, 2009.

24. Wu D, Zhou Y, Pan H, Zhou J, Fan Y and Qu P: microRNA-99a inhibiting cell proliferation, migration and invasion by targeting fibroblast growth factor receptor 3 in bladder cancer. Oncol Lett 7: 1219-1224, 2014

25. Hu X, Macdonald DM, Huettner PC, Feng Z, El Naqa IM, Schwarz JK, Mutch DG, Grigsby PW, Powell SN and Wang X: A miR-200 microRNA cluster as prognostic marker in advanced ovarian cancer. Gynecol Oncol 114: 457-464, 2009.

26. Xie P, Xu F, Cheng W, Gao J, Zhang Z, Ge J, Wei Z, Xu X and Liu Y: Infiltration related miRNAs in bladder urothelial carcinoma. J Huazhong Univ Sci Technolog Med Sci 32: 576-580, 2012.

27. Nam EJ1, Yoon H, Kim SW, Kim H, Kim YT, Kim JH, Kim JW and Kim S: MicroRNA expression profiles in serous ovarian carcinoma. Clin Cancer Res 14: 2690-2695, 2008.

28. Sun T, Wang C, Xing J and Wu D: miR-429 modulates the expression of c-myc in human gastric carcinoma cells. Eur J Cancer 47: 2552-2559, 2011.

29. Sun Y, Shen S, Tang H, Xiang J, Peng Y, Tang A, Li N, Zhou W, Wang Z, Zhang D, et al: miR-429 identified by dynamic transcriptome analysis is a new candidate biomarker for colorectal cancer prognosis. OMICS 18: 54-64, 2014

30. Liu X, Liu Y, Wu S, Shi X, Li L, Zhao J and Xu H: Tumor-suppressing effects of miR-429 on human osteosarcoma. Cell Biochem Biophys 70: 215-224, 2014.

31. Ye ZB, Ma G, Zhao YH, Xiao Y, Zhan Y, Jing C, Gao K, Liu ZH and Yu SJ: miR-429 inhibits migration and invasion of breast cancer cells in vitro. Int J Oncol 46: 531-538, 2015.

32. Wang Y, Li M, Zang W, Ma Y, Wang N, Li P, Wang T and Zhao G: MiR-429 up-regulation induces apoptosis and suppresses invasion by targeting Bcl-2 and SP-1 in esophageal carcinoma. Cell Oncol (Dordr) 36: 385-394, 2013.

33. Dynan WS and Tjian R: The promoter-specific transcription factor Sp1 binds to upstream sequences in the SV40 early promoter. Cell 35: 79-87, 1983.
34. Chang WC and Hung JJ: Functional role of post-translational modifications of Sp1 in tumorigenesis. J Biomed Sci 19: 94, 2012.

35. Kadonaga JT, Courey AJ, Ladika J and Tjian R: Distinct regions of Sp1 modulate DNA binding and transcriptional activation. Science 242: 1566-1570, 1988.

36. Philipsen S and Suske G: A tale of three fingers: The family of mammalian Sp/XKLF transcription factors. Nucleic Acids Res 27: 2991-3000, 1999.

37. Narayan VA, Kriwacki RW and Caradonna JP: Structures of zinc finger domains from transcription factor Sp1. Insights into sequence-specific protein-DNA recognition. J Biol Chem 272: 7801-7809, 1997.

38. Black AR, Black JD and Azizkhan-Clifford J: Sp1 and krüppel-like factor family of transcription factors in cell growth regulation and cancer. J Cell Physiol 188: 143-160, 2001.

39. Beishline K and Azizkhan-Clifford J: Sp1 and the 'Hallmarks of Cancer'. FEBS J 282: 224-258, 2015.

40. Sankpal UT, Goodison S, Abdelrahim M and Basha R: Targeting Sp1 transcription factors in prostate cancer therapy. Med Chem 7: 518-525, 2011.

41. Yue L, Li L, Liu F, Hu N, Zhang W, Bai X, Li Y, Zhang Y, Fu L, Zhang $X$ and Ye L: The oncoprotein HBXIP activates transcriptional coregulatory protein $\mathrm{LMO} 4$ via Sp1 to promote proliferation of breast cancer cells. Carcinogenesis 34: 927-935, 2013.

42. Bonofiglio D, Qi H, Gabriele S, Catalano S, Aquila S, Belmonte M and Andò S: Peroxisome proliferator-activated receptor gamma inhibits follicular and anaplastic thyroid carcinoma cells growth by upregulating p21Cip1/WAF1 gene in a Sp1-dependent manner. Endocr Relat Cancer 15: 545-557, 2008.

43. Yin P, Zhao C, Li Z, Mei C, Yao W, Liu Y, Li N, Qi J, Wang L, Shi $\mathrm{Y}$, et al: $\mathrm{Sp} 1$ is involved in regulation of cystathionine gamma-lyase gene expression and biological function by PI3K/Akt pathway in human hepatocellular carcinoma cell lines. Cell Signal 24: 1229-1240, 2012

44. Huang C and Xie K: Crosstalk of Sp1 and Stat3 signaling in pancreatic cancer pathogenesis. Cytokine Growth Factor Rev 23: 25-35, 2012.

45. Pathi S, Jutooru I, Chadalapaka G, Nair V, Lee SO and Safe S: Aspirin inhibits colon cancer cell and tumor growth and downregulates specificity protein $(\mathrm{Sp})$ transcription factors. PLoS One 7: e48208, 2012.

46. Xu Y, Zhao F, Wang Z, Song Y, Luo Y, Zhang X, Jiang L, Sun Z, Miao Z and Xu H: MicroRNA-335 acts as a metastasis suppressor in gastric cancer by targeting Bcl-w and specificity protein 1. Oncogene 31: 1398-1407, 2012.

47. Wang YT, Chuang JY, Shen MR, Yang WB, Chang WC and Hung JJ: Sumoylation of specificity protein 1 augments its degradation by changing the localization and increasing the specificity protein 1 proteolytic process. J Mol Biol 380: 869-885, 2008

48. Hsu TI, Wang MC, Chen SY, Yeh YM, Su WC, Chang WC and Hung JJ: Sp1 expression regulates lung tumor progression. Oncogene 31: 3973-3988, 2012.

49. Trisciuoglio D, Iervolino A, Candiloro A, Fibbi G, Fanciulli M, Zangemeister-Wittke U,Zupi G and Del Bufalo D: Bcl-2 induction of urokinase plasminogen activator receptor expression in human cancer cells through Sp1 activation: involvement of ERK1/ERK2 activity. J Biol Chem 279: 6737-6745, 2004.

50. De Siervi A, Marinissen M, Diggs J, Wang XF, Pages G and Senderowicz A: Transcriptional activation of p21 (waf1/cip1) by alkylphospholipids: Role of the mitogen-activated protein kinase pathway in the transactivation of the human p21(waf1/cip1) promoter by Sp1. Cancer Res 64: 743-750, 2004.

51. Wang H, Li M, Zhang R, Wang Y, Zang W, Ma Y, Zhao G and Zhang G: Effect of miR-335 upregulation on the apoptosis and invasion of lung cancer cell A549 and H1299. Tumour Biol 34: 3101-3109, 2013.

52. Jiang J, Lv X, Fan L, Huang G, Zhan Y, Wang M and Lu H: MicroRNA-27b suppresses growth and invasion of NSCLC cells by targeting Sp1. Tumour Biol 35: 10019-10023, 2014.

53. Mao Y, Chen H, Lin Y, Xu X, Hu Z, Zhu Y, Wu J, Xu X, Zheng $\mathrm{X}$ and Xie L: microRNA-330 inhibits cell motility by downregulating Sp1 in prostate cancer cells. Oncol Rep 30: 327-333, 2013.

54. Wang F, Li Y, Zhou J, Xu J, Peng C, Ye F, Shen Y, Lu W, Wan X and Xie X: miR-375 is down-regulated in squamous cervical cancer and inhibits cell migration and invasion via targeting transcription factor SP1. Am J Pathol 179: 2580-2588, 2011. 